Economics Development Analysis Journal 7 (2)(2018)

\title{
Strategi Pengembangan Sentra UMKM Ikan Pindang di Desa Tasikagung Kabupaten Rembang
}

\author{
Muhammad Riza Adhitama ${ }^{\bowtie}$
}

Jurusan Ekonomi Pembangunan, Fakultas Ekonomi, Universitas Negeri Semarang

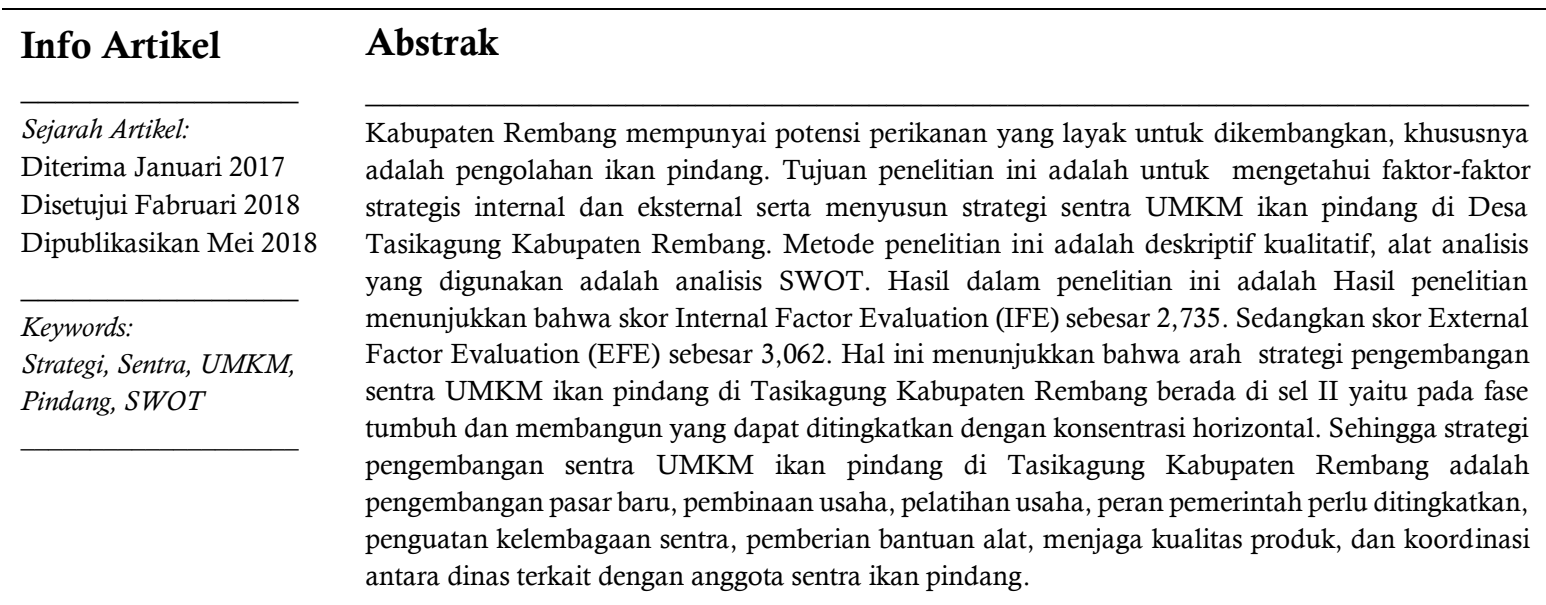

\begin{abstract}
Rembang Regency has fishery potential that is feasible to be developed, especially is in processing of pindang fish. The purpose of this research is to know the internal and external strategic factors and developed progam UMKM center of bloater in village Tasikagung, Rembang Regency. The results showed that the Internal Factor Evaluation (IFE) score was 2.735, while the External Factor Evaluation (EFE) score was 3.062. This indicatesd that the direction of the development strategy of UMKM center of bloater in Tasikagung Rembang Regency was in cell II that was in growth and built phase which can be increased with horizontal concentration. Hence, the development strategy of bloater UMKM center in Tasikagung Rembang Regency is the development of new market, business coaching, business training, government role need to be improved, strengthening of central institute, giving tool aid, maintaining product quality, and coordination between offices related to members of bloater center.
\end{abstract}

\footnotetext{
${ }^{\square}$ Alamat korespondensi:

Ruang Jurnal Gedung L FE UNNES, Sekaran Gunungpati

Semarang, 50229, Indonesia

E-mail: Rizaadhitama5@gmail.com@gmail.com
}

ISSN 2252-6965 


\section{PENDAHULUAN}

Keberadaan Usaha Mikro Kecil dan Menengah (UMKM) dalam perekonomian suatu Negara memiliki peran yang penting. Dalam kenyataannya menunjukkan bahwa UMKM mempunyai peranan usaha, yaitu dapat dilihat dari kontribusinya terhadap Produk Domestik Bruto (PDB), ekspor nonmigas, penyerapan tenaga kerja, dan peningkatan kualitas sumber daya manusia yang cukup berarti (M.Irfan dalam Anoraga, 2002).

Perkembangan UMKM masih belum menjalankan fungsi dan perannya secara maksimal. Banyak kendala yang dihadapi seperti: masalah keterbatasan modal, teknik produksi, bahan baku, pemasaran, manajemen serta teknologi (Kuncoro, 2010).Menurut Kuncoro (2007) Pengembangan UMKM adalah cara yang dinilai besar peranannya dalam pengembangan industri manufaktur. Pengembangan UMKM akan membantu mengatasi masalah pengangguran sehingga bisa memperbesar lapangan kerja dan kesempatan usaha yang pada akhirnya akan mendorong pembangunan daerah dan kawasan perdesaan.

Kabupaten Rembang merupakan salah satu kabupaten yang berpotensi untuk dikembangkan dalam sektor UMKM. Salah satu UMKM tersebut adalah UMKM pengolahan hasil perikanan. Menurut BPS (2016) produksi perikanan laut Kabupaten Rembang mencapai 67.644 ton pada tahun 2014, namun pada tahun 2015 jumlah produksi perikanan laut mengalami penurunan menjadi 66.744 ton. Hal tersebut membuat Kabupaten Rembang sebagai wilayah dengan produksi sektor perikanan terbesar di Jawa Tengah.

Perlunya strategi pengembangan guna memanfaatkan sektor perikanan sebagai sektor unggulan guna meningkatkan pendapatan daerah sehingga dapat memberi dampak terhadap perekonomian daerah dan kesejahteraan bagi masyarakat sekitar khususnya masyarakat pesisir.

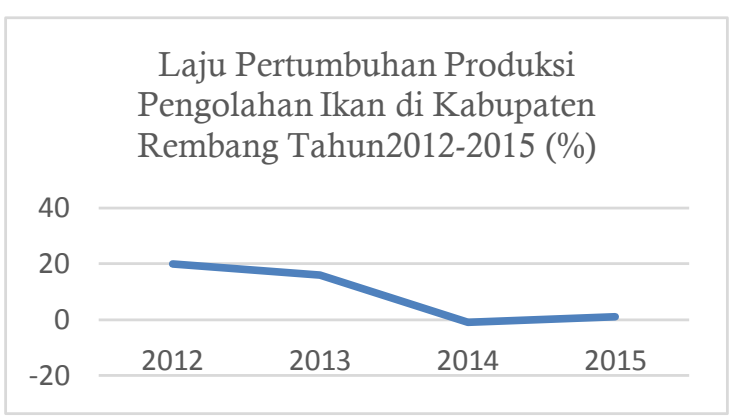

Gambar 1. Laju Pertumbuhan Produksi Pengolahan Ikan di Kabupaten Rembang Tahun2012-2015 (\%)

Sumber: DKP 2016

Dilihat dari gambar 1 mengenai laju pertumbuhan pertumbuhan pengolahan ikan dari tahun 2013-2015 mengalami penurunan yang signifikan yaitu dari $20 \%$ menjdi $1 \%$. Masalah ini harus menjadi perhatian bagi pemerintah Kabupaten Rembang dan stakeholder dalam upaya menjaga konsistensi laju pertumbuhan pengolahan ikan guna mendukung perekonomian daerah dan kesejahteraan masyarakat.

Kegiatan UMKM pengolahan ikan di Kabupaten Rembang dipusatkan atau disentrakan di Desa Tasikagung Kabupaten Rembang, karena pusat Tempat Pelelangan Ikan (TPI) terbesar di Kabupaten Rembang pada tahun 2016 yang mencapai 36.747 ton (DKP 2016).

Sentra mempunyai pengertian suatu wilayah dimana didalamnya terdapat pengelompokan industri-industri yang sejenis. Sentra perikanan di Desa Tasikagung Kabupaten Rembang terdapat berbagai olahan jenis ikan, namun yang paling berkontribusi dalam produksi pengolahan ikan di Tasikagung adalah jenis olahan ikan pindang. 
Tabel 1. Produksi Pengolahan Ikan di Kabupaten Rembang Tahun 2013-2015

\begin{tabular}{llll}
\hline Jenis & \multicolumn{3}{l}{ Produksi (ton) } \\
\cline { 2 - 4 } Pengolahan & 2013 & 2014 & 2015 \\
\hline Kerupuk & & & \\
Ikan & 946,8 & 952 & 1.000 \\
Pindang & 57.360 & 58.102 & 58.000 \\
Terasi & 112,2 & 115 & 125 \\
\hline
\end{tabular}

Sumber: DKP Kab Rembang 2016

Tabel 1 produksi pengolahan pindang merupakan produksi terbesar dan mengalami penurunan pada tahun 2015 sebesar 102 ton. Guna mengetahui penyebab turunnya produksi tersebut maka dilakukan observasi.

Hasil observasi menunjukka bahwa terdapat berbagai hambatan yang menyebabkan produksi pengolahan ikan pindang menurun. Hambatan yang paling utama diantaranya adalah hambatan ketersediaan bahan baku dan hambatan pasar. Hal ini merupakan masalah yang harus diselesaiakan sehingga perlunya strategi guna mengatasi permasalahan tersebut, dengan adanya sumberdaya lokal yang melimpah mampu meningkatkan kesejahteraan masyarakat dan mampu merangsang kegiatan pembangunan perekonomian daerah. Tujuan dari penelitian ini adalah untuk mengetahui faktor-faktor strategis internal dan eksternal serta menyusun strategi sentra UMKM ikan pindang di Desa Tasikagung Kabupaten Rembang.

\section{METODE PENELITIAN}

Alat analisis yang digunakan dalam penelitian ini adalah anlisis SWOT. Analisis SWOT dalam (Rangkuti, 2015) adalah suatu alat analisis untuk mengevaluasi faktor internal dan faktor eksternal organisasi atau perusahaan sehingga dapat memberikan informasi mengenai isu-isu penting bagi organisasi atau perusahaan. Analisis SWOT dimulai dari faktor internal dengan mengidentifikasi aspek positif, yaitu strength (kekuatan) dan aspek negatif, yaitu weakness (kelemahan). Sedangkan faktor eksternal dengan mengidentifikasi opportunities (peluang) dan threat (ancaman). Selain itu juga dapat digunakan untuk membuat strategi yang akan digunakan setelah melihat kekuatan, kelemahan, peluang, dan ancaman. Berdasarkan SWOT matrix, dapat disusun empat strategi utama yaitu; SO, WO, ST dan WT. Masingmasing strategi ini memiliki karakteristik tersendiri dan hendaknya dalam implementasi strategi selanjutnya dilaksanakan secara bersama-sama dan saling mendukung satu sama lain.

\section{HASIL DAN PEMBAHASAN}

Penelitian ini membahas tentang strategi pengembangan sentra UMKM ikan pindang di Tasikagung Kabupaten Rembang menggunakan analisis SWOT (Strenght, Weakness, Opportunity, Threats). Hasil penelitian yang telah dilakukan menghasilkan identifikasi faktor internal dan eksternal.

Identifikasi faktor internal dalam pengembangan strategi sentra UMKM ikan pindang di Tasikagung Kabupaten Rembang. Berikut hasil identifikasi faktor internal sentra UMKM ikan pindang:

\section{Kekuatan}

a. Dekat dengan bahan baku

b. Tenaga kerja dekat dengan lokasi usaha

c. Kemudahan dalam mengakses sumber pinjaman modal

d. Penerapan spesialisai kerja

e. Produk ikan pindang di sentra Tasikagung berkualitas tinggi

f. Adanya paguyuban pemindang yang berbentuk sentra

\section{Kelemahan}

a. Rendahnya tingkat ketrampilan SDM dalam bersaing di pasar modern

b. Kurangnya fasilitas peralatan /teknologi dalam mendukung proses produksi

c. Sulit dalam mencari pasar baru

d. Kemasan produk yang masih sederhana

e. Status sentra hanya sebagai formalitas 
Identifikasi faktor eksternal dalam pengembangan strategi sentra UMKM ikan pindang di Tasikagung Kabupaten Rembang. Berikut hasil identifikasi faktor eksternal sentra UMKM ikan pindang:

\section{Peluang}

a. Perluasan pasar baru

b. Ekspor hasil sentra ikan pindang

c. Bantuan penambahan peralatan /teknologi guna menunjang proses produksi

d. Penguatan kelembagaan sentra

e. Pembinaan usaha sentra ikan pindang

\section{Ancaman}

a. Bahan baku yang sulit dan mahal

b. Tenaga kerja mendekati usia lanjut

c. Kurang maksimalya dukungan dari pemerintah terkait

d. Bantingan harga dari pesaing ikan pindang di daerah lain

e. Tidak adanya kegiatan sentra ikan pindang di Tasikagung

\section{Hasil Rata-Rata Pembobotan dan Rating IFE dan EFE}

Tabel 2. Hasil Skor Pembobotan dan Reting Identifikasi Faktor Internal (IFE)

\begin{tabular}{llll}
\hline $\begin{array}{l}\text { Faktor strategis } \\
\text { Internal }\end{array}$ & & & \\
Kekuatan & & $\mathrm{R}$ & Skor \\
\hline $\begin{array}{l}\text { Dekat dengan } \\
\text { bahan baku }\end{array}$ & 0,135 & 4 & 0,540 \\
$\begin{array}{l}\text { Tenaga kerja } \\
\text { dekat dengan }\end{array}$ & 0,120 & 4 & 0,480 \\
$\begin{array}{l}\text { lokasi usaha } \\
\begin{array}{l}\text { Kemudahan } \\
\text { dalam mengakses }\end{array}\end{array}$ & 0,100 & 3,5 & 0,350 \\
$\begin{array}{l}\text { sumber pinjaman } \\
\text { modal ikan }\end{array}$ & 0,090 & 3,5 & 0,315 \\
$\begin{array}{l}\text { Penerapan } \\
\text { spesialisasi kerja }\end{array}$ & 0,085 & 3 & 0,255 \\
$\begin{array}{l}\text { Produk ik } \\
\text { pindang di sentra }\end{array}$ & & & \\
\hline
\end{tabular}

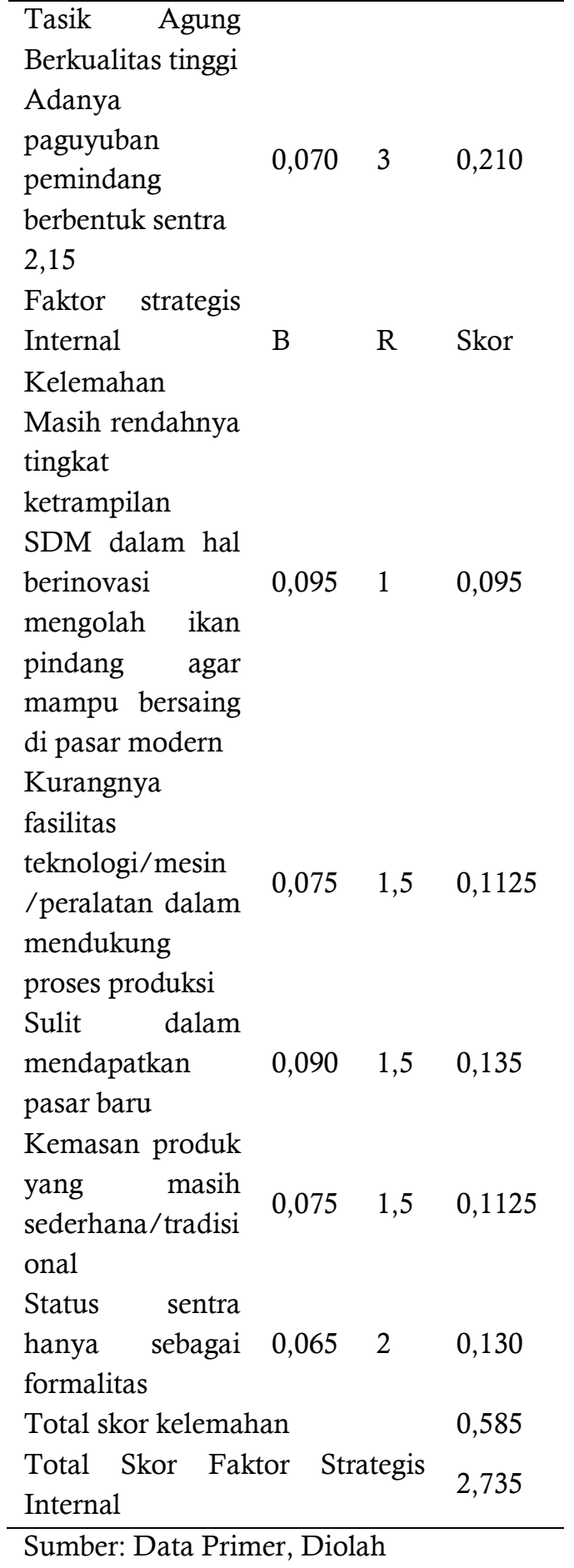

Dari tabel 2 diatas menunjukkan bahwa faktor strategi internal untuk indikator kekuatan yang memperoleh skor pembobotan tertinggi adalah dekat dengan bahan baku sebsesar 0,540. Hal tersebut dikarenakan lokasi TPI sangat dekat dengan lokasi usaha ikan pindang. Dengan dekatnya lokasi bahan baku maka akan 
menguntungkan bagi para pemindang dalam menekan biaya produksi.

Hasil pada strategi internal dengan indikator kelemahan untuk faktor sulit dalam mencari pasar baru menjadi aspek yang memiliki skor pembobotan tertinggi yaitu sebesar 0,135 . Kondisi tersebut menunjukkan bahwa sulitnya mencari pasar baru disebabkan oleh bantingan harga oleh pesaing pemindang dari daerah lain.

Tabel 3. Hasil Rata-Rata Pembobotan dan Rating Identifikasi Faktor Enternal (EFE)

\begin{tabular}{|c|c|c|c|}
\hline $\begin{array}{l}\text { Faktor strategis } \\
\text { Eksternal } \\
\text { Peluang }\end{array}$ & B & $\mathrm{R}$ & Skor \\
\hline Perluasan pasar baru & 0,115 & 3 & 0,345 \\
\hline $\begin{array}{l}\text { Ekspor hasil sentra } \\
\text { ikan pindang }\end{array}$ & 0,055 & 1 & 0,055 \\
\hline $\begin{array}{l}\text { Bantuan } \\
\text { penambahan }\end{array}$ & & & \\
\hline $\begin{array}{lr}\text { perlatan } & \text { teknologi } \\
\text { guna } & \text { menunjang }\end{array}$ & 0,105 & 3 & 0,315 \\
\hline $\begin{array}{l}\text { kegiatan produksi } \\
\text { (Cold storage, pompa } \\
\text { kompresor,dll) }\end{array}$ & & & \\
\hline Penguatan & & & \\
\hline $\begin{array}{l}\text { kelembagaan sentra } \\
\text { ikan pindang }\end{array}$ & 0,090 & 2,5 & 0,225 \\
\hline $\begin{array}{l}\text { Pembinaan usaha } \\
\text { sentra ikan pindang } \\
1,325\end{array}$ & 0,110 & 3,5 & 0,385 \\
\hline Faktor strategis & & & \\
\hline $\begin{array}{l}\text { Eksternal } \\
\text { Ancaman }\end{array}$ & B & $\mathrm{R}$ & Skor \\
\hline $\begin{array}{l}\text { Bahan baku yang } \\
\text { semakin sulit dan } \\
\text { mahal }\end{array}$ & 0,140 & 4 & 0,560 \\
\hline $\begin{array}{l}\text { Tenaga kerja } \\
\text { mendekati usia lanjut }\end{array}$ & 0,080 & 2 & 0,160 \\
\hline $\begin{array}{l}\text { Kurang } \\
\text { maksimalnya } \\
\text { dukungan dari } \\
\text { pemerintah terkait }\end{array}$ & 0,105 & 3,5 & 0,367 \\
\hline $\begin{array}{l}\text { Bantingan harga dari } \\
\text { pesaing ikan pindang } \\
\text { di daerah lain }\end{array}$ & 0,125 & 4 & 0,500 \\
\hline
\end{tabular}

\begin{tabular}{llll}
\hline Tidak & \multicolumn{2}{c}{ adanya } & \\
kegiatan sentra ikan & & & \\
pindang di Tasik & 0,075 & 2 & 0,150 \\
Agung & & \\
Total skor kelemahan & 1,737 \\
Total Skor Faktor Strategis Eksternal & 3,062 \\
\hline Sumber: Data Primer, Diolah
\end{tabular}

Dari tabel 3 menunjukkan bahwa faktor strategi eksternal untuk indikator peluang memperoleh skor pembobotan tertinggi adalah pembinaan usaha yaitu 0,385. Dengan melakukan pembinaan usaha sentra ikan pindang diharapkan dapat meningkatkan kinerja usaha ikan pindang, sehingga mampu untuk menghadapi pesaing lain dari daerah lain.

Hasil strategi eksternal untuk indikator ancaman adalah semakin sulit dan mahalnya bahan baku dengan skor 0,560.. Perlunya peralatan teknologi yaitu cold storage. Cold storage merupakan tempat frezeer room atau ruangan pendingin yang fungsi penggunaannya bertujuan untuk menghindari kontaminasi dari bakteri, dan dapat mempertahankan cita rasa yang disebabkan oleh suhu yang sangat dingin, sehingga apabila ikan dimasukkan kedalam cold storage dapat bertahan lama dan kesegaran ikan tetap terjaga.

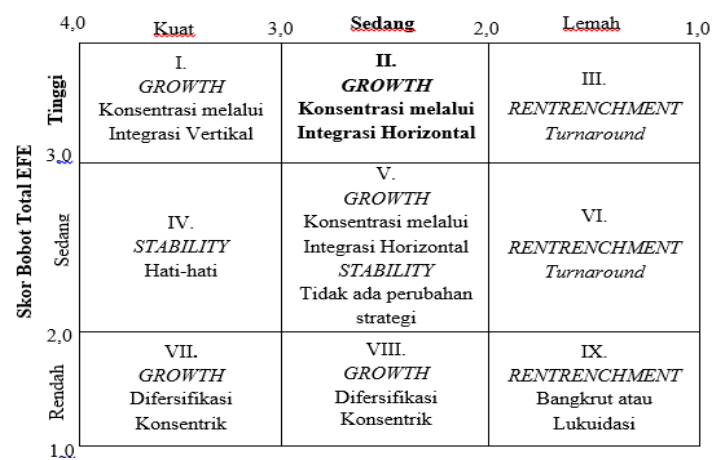

Gambar 2. Matrik Internal dan Eksternal Sumber: Data Primer, Diolah

Hasil dari skor IFE dan EFE menunjukkan bahwa nilai IFE sebesar 2,735 yang tergolong pada kategori sedang dan nilai EFE 3,062 yang tergolong pada kategori tinggi. Dengan hasil tersebut menjadikan arah strategi pengembangan sentra UMKM ikan pindang di 
Tasikagung Kabupaten Rembang berada di sel II pada fase tumbuh dan membangun yang dapat ditingkatkan dengan konsentrasi horizontal. Hasil matrik IE ini sama halnya dengan hasil penelitian dari Shaifur (2015) yang menyatakan bahwa hasil matrik IE berada pada sel II. Pada sel ini, strategi yang umum dilakukan adalah strategi intensif (penetrasi pasar, pengembangan pasar, pengembangan produk) atau strategi integrarif (integrasi ke belakang, integrasi ke depan, integrasi horizontal.

\section{Formulasi Strategi}

\section{Strategi SO}

1. Pengembangan pasar baru diimbangi dengan meningkatkan jumlah produksi ikan pindang

2. Pengadaan pembinaan usaha sentra ikan pindang

Strategi WO

1. Pengadaan pelatihan usaha yang diadakan oleh Dinas terkait

2. Penguatan kelembagaan sentra dengan membuat progam kerja/kebijakan yang bertujuan untuk mengembangkan usaa sentra ikan pindang

3. Peran pemerintah dalam bantuan berupa peralatan perlu ditingkatkan dan perlu adanya inovasi dan penggunaan teknologi yang lebih modern

Strategi ST

1. Pemberian bantuan alat berupa cold storage

2. Menjaga kualitas produk ikan pindang untuk bersaing dengan produk ikan pindang daerah lain

\section{Strategi WT}

Perlunya koordinasi antara dinas terkait dengan para anggota sentra ikan pindang guna menciptakan perumusan strategi pengembangan sentra UMKM ikan pindang di Tasikagung.

\section{SIMPULAN}

Berdasarakan pembahasan diatas maka kesimpulan dalam penelitian ini adalah faktor strategi internal aspek kekuatan dalam strategi pengembangan sentra UMKM ikan pindang di
Tasikagung Kabupaten Rembang adalah dekat dengan bahan baku dengan mendapatkan skor sebesar 0,540. Faktor strategi internal aspek kelemahan dalam strategi pengembangan sentra UMKM ikan pindang di Tasikagung Kabupaten Rembang adalah sulit mendapatkan pasar baru dengan mendapatkan skor sebesar 0,135.

Faktor strategi eksternal aspek peluang dalam strategi pengembangan sentra UMKM ikan pindang di Tasikagung Kabupaten Rembang adalah pembinaan usaha sentra UMKM ikan pindang di Tasikagung dengan mendapatkan skor sebesar 0,385. Faktor strategi eksternal aspek ancaman dalam strategi pengembangan sentra UMKM ikan pindang di Tasikagung Kabupaten Rembang adalah Bahan baku yang semakin sulit dan mahal dengan mendapatkan skor sebesar 0,560.

Strategi pengembangan sentra UMKM ikan pindang di Tasikagung Kabupaten Rembang antara lain: pengembangan pasar baru diimbangi dengan meningkatkan jumlah produksi ikan pindang, pengadaan pembinaan usaha sentra ikan pindang, peran pemerintah dalam bantuan berupa peralatan perlu ditingkatkan dan perlu adanya inovasi dan penggunaan teknologi yang lebih modern, pengadaan pelatihan usaha yang diadakan oleh Dinas terkait, penguatan kelembagaan sentra dengan membuat progam kerja/kebijakan yang bertujuan untuk mengembangkan usaha sentra ikan pindang, pemberian bantuan alat berupa cold storage, Menjaga kualitas produk ikan pindang untuk bersaing dengan produk ikan pindang daerah lain, perlunya koordinasi antara dinas terkait dengan para anggota sentra ikan pindang guna menciptakan perumusan strategi pengembangan sentra UMKM ikan pindang di Tasikagung.

\section{DAFTAR PUSTAKA}

Anogara, P. \& J. Sudantoko. Koperasi, Kewirausahaan dan Usaha Kecil. (Jakarta: Rineka Cipta, 2002).

[BPS] Badan Pusat Statistika Kabupaten Rembang. 2016. Rembang dalam angka 2016. Rembang. BPS 
[DKP] Dinas Kelautan dan Perikanan. 2015. Profil Dinas Kelautan dan

Perikanan Jawa Tengah Tahun 2015. Departemen Kelautan dan Perikanan. Jakarta.

Kuncoro, Mudrajat. 2007. Usaha Kecil di Indonesia: Profil, Masalah, dan Strategi Pemberdayaan.
Kuncoro, Mudrajad. 2010. Dasar-Dasar Ekonomika Pembangunan, UPP STIM

YKPN Yogyakarta.

Rangkuti. 2015. Analisis SWOT: Teknik Membedah Kasus Bisnis, Cetakan keduapuluh. Jakarta: Gramedia Pustaka. 